\title{
IMPLIKASI FAKTOR MAKROEKONOMI TERHADAP KINERJA SISTEM PERBANKAN GANDA DI INDONESIA
}

\author{
Jannatul Liutammima Musta'in ${ }^{1}$, Faaza Fakhrunnas ${ }^{2}$ \\ Program Studi Ekonomi Pembangunan \\ Fakultas Ekonomi dan Bisnis, Universitas Ahmad Dahlan \\ Program Studi Ilmu Ekonomi \\ Fakultas Ekonomi, Universitas Islam Indonesia
}

\begin{abstract}
Since the implementation of Banking Regulation Number 10 year 1998, Indonesia has two banking systems that must be maintained and controlled, is conventional banking and Islamic banking. Indonesia as a developing country is very vulnerable to economic turmoil related to macroeconomic factors. The problematic crisis experienced by Indonesia in 1998 has been a proof of the weakness of the resilience of the banking system in Indonesia, especially in conventional banking. The condition of syariah banking in Indonesia which majority originated from the Islamic bank window has the potential to have a high degree of vulnerability during a crisis. Let's say in the management of liquidity management is still dependent on the parent company, namely conventional banking. If conventional banking is experiencing financial difficulties due to unfavorable macroeconomic conditions, then the management of subsidiaries' liquidity also has the possibility to be disturbed. Based on the results of data analysis that has been described previously shows that macroeconomic factors such as the interest rate of Bank Indonesia, inflation rate and GDP growth have a significant influence on the performance of banks both measured by the level of profit and risk. This shows that the banking industry in Indonesia should pay great attention to the dynamics of macroeconomic factors that are happening. This should be done by the bank to be able to respond appropriately to the macroeconomic conditions that are and will happen to the fore.
\end{abstract}

$\begin{array}{ll}\text { Keywords } & \text { : Macroeconomics, Dual Banking System, Panel Data Estimation } \\ \text { Correspondence to } & \text { : jannatul.mustain@ep.uad.ac.id, fakhrunnasfaaza@gmail.com }\end{array}$

\section{ABSTRAK}

Sejak diterapkannya Undang-Undang No.10 Tahun 1998, Indonesia memiliki dua sistem perbankan yang harus dijaga dan dikendalikan yakni perbankan konvensional serta perbankan syariah. Indonesia sebagai negara berkembang sangat rentan terhadap gejolak ekonomi terkait faktor makroekonomi. Problematika krisis yang dialami oleh Indonesia ditahun 1998 menjadi bukti terkait lemahnya daya tahan sistem perbankan di Indonesia, terutama pada perbankan konvensional. Kondisi perbankan syariah di Indonesia yang mayoritas berawal dari islamic bank window berpotensi untuk memiliki tingkat kerentanan yang tinggi ketika terjadi krisis. Misalkan saja dalam 
pengelolaan manajemen likuiditas yang masih bergantung kepada perusahan induk, yakni perbankan konvensional. Jika perbankan konvensional sedang mengalami kesulitan keuangan karena kondisi makro ekonomi yang kurang baik, maka manajemen likuditas anak perusahaan pun memiliki kemungkinan untuk terganggu. Berdasarkan hasil analisa data yang telah dijelaskan sebelumnya menunjukan bahwa faktor makro ekonomi seperti tingkat suku bunga Bank Indonesia, tingkat inflasi dan pertumbuhan GDP memiliki pengaruh yang signifikan terhadap kinerja perbankan baik diukur dengan tingkat keuntungan maupun resiko. Hal ini menunjukan bahwa industri perbankan di Indonesia harus memberikan perhatian yang besar terhadap dinamika faktor makro ekonomi yang sedang terjadi. Hal tersebut harus dilakukan oleh bank untuk dapat memberikan respon secara tepat terhadap kondisi ekonomi makro yang sedang dan akan terjadi kedepan.

Kata Kunci Korespondensi
: Makro Ekonomi, Sistem Perbankan Ganda, Estimasi Data Panel : jannatul.mustain@ep.uad.ac.id, fakhrunnasfaaza@gmail.com

\section{PENDAHULUAN / INTRODUCTION}

Indonesia sebagai negara berkembang akan selalu meningkatkan institusi keuangannya seperti institusi perbankan (Aviliani et al., 2015). Hal ini dijelaskan oleh Mishkin (2001) dan Silalahi et al. (2015), bahwa bank merupakan sumber institusi penting dan utama bagi pembiayaan eksternal dalam suatu bisnis hampir di semua negara. Fungsi bank sebagai intermediary institution memiliki peran strategis bagi pengembangan perekonomian suatu negara. Kinerja bank yang baik secara individual maupun dalam suatu sistem diharapkan dapat meningkatkan kontribusinya dalam perekonomian, sehingga penting untuk dipastikan bahwa sistem keuangan dan perekonomian di suatu negara juga berjalan dengan lancar dan efisien sesuai dengan peran perbankan yang begitu besar terhadap kondisi suatu negara (Alper dan Albar, 2011; Aviliani et al., 2015) dan Indonesia sebagai negara yang menerapkan sistem perbankan ganda sejak tahun 1998 yakni perbankan konvensional dan Syariah, maka perlu adanya keseimbangan dalam pelaksanaan kebijakan guna menunjang kinerja masingmasing sistem perbankan (Ascarya dan Yumanita, 2009).

Berdasarkan Laporan Islamic Finance Service Board 2016, perkembangan industri keuangan syariah sangat pesat yakni mencapai USD 1,87 Triliun atas total aset keuangan syariah di dunia. Kondisi ini juga terjadi padaperkembangan industri keuangan syariah di Indonesiati, dimana sejak munculnya bank syariah ditahun 1992, market share perbankan syariah saat ini terus meningkat hingga mencapai 5,13\% (OJK, 2016). Dalam enam tahun terakhir, OJK menghitung bahwa aset perbankan syariah tumbuh lebih dari dua kali lipat dalam kurun waktu 2011-2016. Hal tersebut dapat dilihat dari jumlah aset perbankan syariah pada tahun 2011 yang hanya mencapai 145.5 triliun rupiah berkembang pesat menjadi 356.504 Triliun rupiah per Desember 2016 (OJK, 2016).

Kondisi perkembangan bank syariah yang sangat pesat, tidak dapat dijadikan sebagai jaminanatas bank syariah rentan 
dengan resiko kegagalan dalam melakukan kegiatan bisnis. Studi kasus pada salah satu bank syariah di Turkey yakniIhlas Finance House,mengalami kebangkrutan karena tidak mampu mengatasi faktor makroekonomi yang sedang bergejolak (Ali, 2007). Bank tersebut gagal karena tidak bisa merespon dengan baik keadaan perekonomian yang dinamis di Turkey pada tahun kurun waktu 2000-2001. Melihat kondisi perbankan syariah di Indonesia yang mayoritas berawal dari islamic bank window berpotensi untuk memiliki tingkat kerentanan yang tinggi ketika terjadi krisis. Misalkan saja dalam pengelolaan manajemen likuiditas yang masih bergantung kepada perusahan induk, yakni perbankan konvensional. Jika perbankan konvensional sedang mengalami kesulitan keuangan karena kondisi makro ekonomi yang kurang baik, maka manajemen likuditas anak perusahaan pun memiliki kemungkinan untuk terganggu.

Hal tersebutlah yang menjadikan kondisi makro ekonomi menjadi sangat penting untuk diperhatiakn oleh perbankan dalam menjalankan aktivitas bisnis yang dilakukan guna menjaga stabilitas keuangan. Kondisi ini menarik perhatian peneliti untuk melakukan penelitian lebih lanjut mengenai implikasi faktor makro ekonomi terhadasp kinerja sistem perbankan ganda di IndonesiaDalam penelitian ini terdiri dari beberapa bagian yang pertama adalah pendahuluan, kedua dan ketiga adalah kerangka teori, diskusi serta analisis. Dan yang terakhir adalah kesimpulan.

\section{Kerangka teori}

\section{Faktor Makroekonomi dan}

Sistem Kinerja Perbankan

\section{Ganda}

Sejak diberlakukannya Undang Undang No.10 Tahun 1998 terkait pelaksanaan sistem perbankan ganda di Indonesia yakni perbankan konvensional dan perbankan Syariah, Bank Indonesia memiliki kewajiban dalam membentuk kebijakan perbankan yang seimbang untuk menunjang kinerja masing-masing sistem perbankan (Ascarya dan Yumanita, 2009). Hal ini ditunjang oleh Peraturan Bank Indonesia Nomor 13/1/PBI/2011 tentang Penilaian Tingkat Kesehatan Bank Umum, bahwa kinerja bank merupakan salah satu faktor yang ada dalam penilaian tingkat kesehatan suatu bank, meliputi penerapan tata kelola yang baik (Good Corporate Governance), rentabilitas, dan permodalan (Aviliani et al., 2015).

Studi empirik mengenai faktor makroekonomi telah banyak dilakukan oleh beberapa peneliti baik yang berkaitan langsung dengan kinerja perbankan maupun yang dikaitkan dengan kondisi perbankan lainnya. Dalam konteks makroekonomi, tingkat pertumbuhan ekonomi akan memiliki dampak langsung terhadap kinerja perbankan. Hal ini disebabkan oleh pertumbuhan ekonomi yang baik akan meningkatkan perekenomian suatu masyarakat dalam suatu negara. Larionova dan Varlamova (2014) menjelaskan semakin baik pertumbuhan ekonomi suatu negara maka akan memberikan lebih banyak keleluasaan perbankan dalam melakukan penghimpunan dan penyaluran dana kepada masyarakat.Zarrouk, Ben Jedidia, dan Moualhi (2016) juga membuktikan bahwa dengan kinerja bank konvensional akan semakin baik, jika kondisi peningkatan pertumbuhan ekonomi suatu negara dalam keadaan baik.

Pada konsep perbankan syariah, Qathani et.al (2016) menerangkan bahwa bank syariah memiliki performa yang baik,meskiadanya guncangan ekonomi dunia pada tahun 1998-2012. Kondisi ini dapat dilihat dari tingkat keuntungan perbankan syariah yang lebih baik seirin3g dengan kondisi Gross Domestic 
Product (GDP) dan harga minyak yang terus mengalami pasang surut (Alqahtani, Mayes, dan Brown, 2016). Pengaruh faktor-faktor ekonomi dalam ruang lingkup geografis yang berbeda ternyata juga berdampak secara singifikan terhadap Return on Asset (ROA) yang dimiliki oleh perbankan syariah di beberapa wilayah di dunia. Hal ini tentunya bergantung kepada kondisi makro ekonomi tertentu yang sedang dialami oleh suatu negara yang memiliki perbankan, terutama perbankan Islam.

Tidak ketinggalan, inflasi juga memiliki andil yang signifikan dalam menentukan kinerja perbankan (Masood \& Ashraf, 2012). Zarrouk et.al (2016) menjelaskan bahwa inflasi dapat mempengaruhi operasional cost yang dikeluarkan oleh perbankan. Semakin tinggi nilai inflasi yang ada maka semakin besar operational cost yang akan dikeluarkan oleh perbankan. Lebih jauh, dalam sebuah kompetisi bisnis, dua sistem perbankan, yakni bank syariah dan bank konvensional menjadi hal yang juga menarik untuk dikaji lebih dalam dimana produk-produk perbankan pun ternyata tidak luput dari pengaruh faktor makro ekonomi secara langsung (Meslier, Risfandy, \& Tarazi, 2016).

Dalam hal membandingkan antara kinerja perbankan syariah dan konvensional tersebut, beberapa kajian yang telah dilakukan menjelaskan bahwa perbankan syariah secara umum memiliki proses recovery yang lebih bagus ketika menghadapi krisis ekonomi dunia (Olson \& Zoubi, 2016). Hal tersebut ditunjukan dengan stabilitias return on asset dan return on equity sebelum, saat dan setelah krisis ekonomi dunia berlangsung. Dengan penemuan yang tidak sama, penelitian lain mengatakan bahwa ternyata tidak ada perbedaan yang sigifikan antara perbankan syariah dan konvensional ketika krisis terjadi pada tahun 2007-2008 (Bourkhis \& Nabi, 2013). Namun demikian, dalam kaitannya mengenai faktor makro ekonomi dalam mempengaruhi kinerja keuangan perbankan, bank konvensional memiliki determinan yang cenderung sama seperti halnya GDP dan Interest rate (Rashid \& Jabeen, 2016). Dari fakta tersebut tentunya menjadi hal yang menarik untuk dikaji dan dikembangkan lebih mendalam mengenai kerentanan perbankan yang menggunakan dual banking system yang terbagi menjadi bank syariah dan konvensional dalam melakukan aktivitas bisnis yang dilakukannya.

\section{Kerangka Konseptual}

Pembahasan studi ini mengikuti tujuan penelitian yang dilakukan yakni setelah adanyaformalasi atas variabel dari sistem kinerja perbankan konvensional maupun Islam,selanjutnya di interaksikan dengan adanya penerapan faktor makroekonomi. 
Gambar 1. Kerangka Konseptual

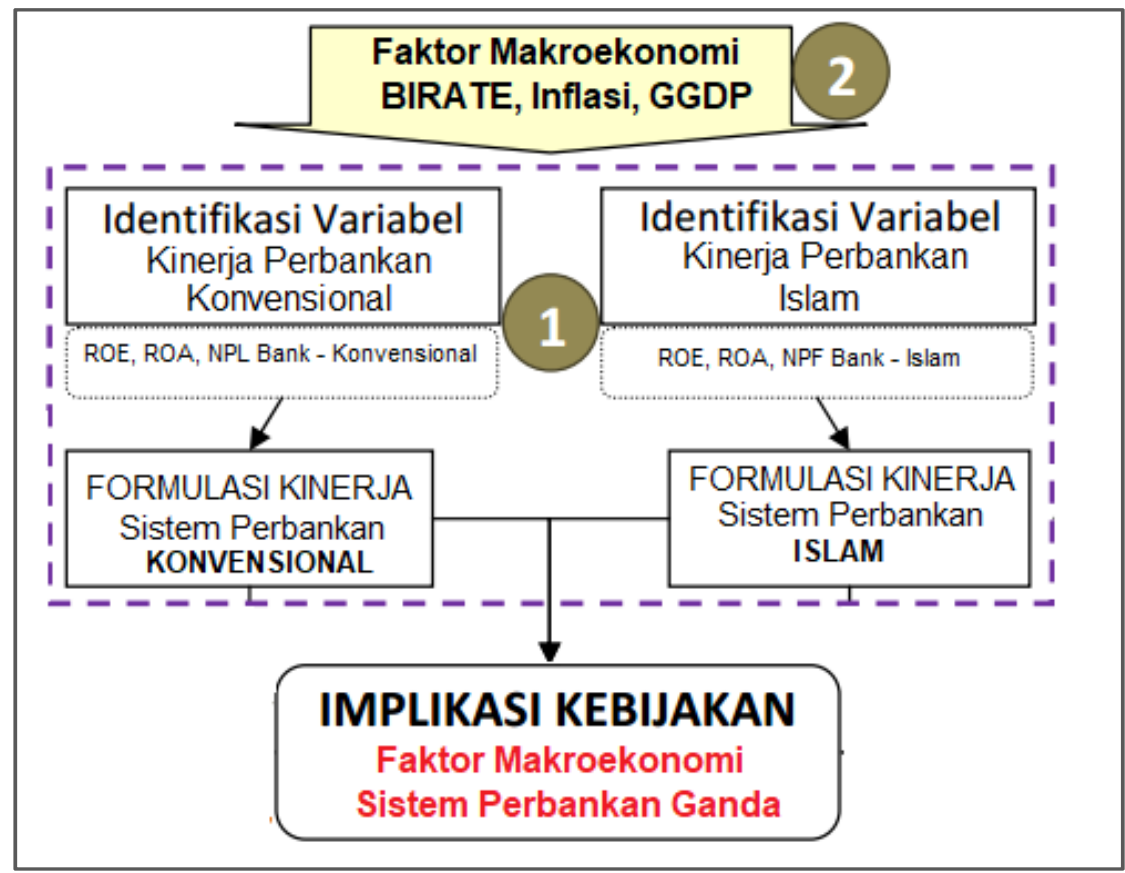

Sumber: Adaptasi dari Ascarya dan Yumanita (2009)

\section{METODE PENELITIAN / METHODS}

Penelitian ini menggunakan data panel untuk mengetahui kerentanan kinerja perbankan yang menggunakan dual banking system terhadap dinamika makro ekonomi yang terjadi di Indonesia. Sampel yang digunakan dalam penelitian ini berjuamlah 18 bank yang terdiri dari 9 bank syariah dan 9 bank konvensional yang secara struktur kepemilikan terafiliasi satu dengan lainnya. Padaumumnya, perbankan syariah dalam sampel tersebut berawal dari islamic bank window yang kemudian menjadi full-fledged bank syariah. Dalam proses pengumpulan data, peneliti menggunakan quarterly data perbankan konvensional dan syariah yang dimulai padatahun 2010 Q4 - 2016 Q3. Data tersebutdiperoleh langsung dari website resmi Bank Indonesia.

Dalam studi ini, peneliti memiliki tiga variabel dependen yang digunakan untuk mengukur kinerja perbankan dari sisi profit dan resiko. Dari sisi profit terdiri dari Return On Asset (ROA) yang dihitung dar itingkat keuntungan dibagi dengan aset perbankan dan Return On Equity (ROE) yang dapat diperoleh dengan menghitung tingkat keuntungan dibagi dengan total modal. Sedangkan Non Performing Loan (NPL) digunakan sebagai proksiresiko yang diukur dari jumlah kredit atau pembiayaan macet dibagi dengan jumlah total kredit atau pembiayaan yang diberikan oleh perbankan. Sementara itu, variabel independen dalam penelitian ini terdiri dari tingkat suku bunga Bank Indonesia (SBI), tingkat inflasi (INF) dan tingkat pertumbuhan ekonomi (GGDP).

Dengan mengadopsi Random Effect Model (REM) sebagai metodologi, analisa penelitianini akan terbagi menjadi menjadi beberapa bagian, yang pertama adalah untuk melihat tingkat pengaruh variabel makro ekonomi terhadap kinerja perbankan secara 
keseluruhan, kedua adalah mengetahui pengaruh variabel makro terhadap kinerja perbankan konvensional dan yang terkahi

Secaraumum, model yang digunakandalampenelitianiniadalahsebagaibe rikut ;

$\sum$ Kinerja Bank $_{i, t}$

$$
\begin{aligned}
& =\alpha+B I R A T E_{i, t}+I N F_{i, t} \\
& +G G D P_{i, t}+\varepsilon_{i, t}
\end{aligned}
$$

Keterangan:

$\sum$ Kinerja Bank $_{i, t}=$ Return of Equity (ROE), Return of Asset (ROA), Net Peforming Loan (NPL),

Net Peforming Finance

(NPF) bank konvensional, bank Islam (\%)

BIRATE $=$ Suku bunga bank Indonesia (\%)

INF $\quad=$ Inflasi $(\%)$

GGDP $\quad=$ Pertumbuhan PDB $(\%)$ radalah untuk mengetahui pengaruh variabel makro terhadap kinerja perbankan syariah.

\section{HASIL PENELITIAN / RESULTS Hasil Analisa Data}

Menurut Greene (2008), penggunaan data panel pada level perbankan terutama microfinance akan menimbulkan banyak permasalahan seperi heterokedastisitas, autokorelasi, maupun multikolinearitas. Hal ini sudah terlihat dari penggunaan data timeseries pada data panel serta data crosssection yang secara individual serta karakteristik pada setiap data perbankan berbeda - beda, maka dilakukan robust regression treatment pada pelaksanaan estimasi pada tiap - tiap model data panel dengan menggunakan STATA/SE 14.0, sehingga dalam penelitian ini ketiga uji tersebut diabaikan.

Tabel 1. Hubungan Faktor Makro Ekonomi dan Kinerja Keuangan di Perbankan

\begin{tabular}{|c|c|c|c|c|c|c|}
\hline \multirow{2}{*}{ Variabel } & \multicolumn{2}{|c|}{ ROE } & \multicolumn{2}{|c|}{ ROA } & \multicolumn{2}{|c|}{ NPL } \\
\hline & Koef & P-Value & Koef & P-Value & Koef & P-Value \\
\hline Konstanta & 40,3084 & $0,00 * * *$ & $-1,4377$ & 0,437 & $-1,4377$ & 0,43 \\
\hline BIRATE & $-5,2917$ & $0,00 * * *$ & 1,0161 & $0,029 * * *$ & 1,0161 & $0,02 * *$ \\
\hline INF & 1,8179 & $0,00 * * *$ & $-0,4247$ & $0,075 * * *$ & $-0,4243$ & $0,07 *$ \\
\hline GGDP & $-0,2639$ & $0,01 * *$ & 1,4378 & 0,186 & $-1,4378$ & 0,186 \\
\hline Observasi & \multicolumn{2}{|c|}{432} & \multicolumn{2}{|c|}{$\frac{1}{432}$} & \multicolumn{2}{|c|}{423} \\
\hline Grup Panel & \multicolumn{2}{|c|}{18} & \multicolumn{2}{|c|}{18} & \multicolumn{2}{|c|}{9} \\
\hline R-Squared & \multicolumn{2}{|c|}{0,0449} & \multicolumn{2}{|c|}{0,0356} & \multicolumn{2}{|c|}{0,0286} \\
\hline F-Stats & \multicolumn{2}{|c|}{0,0078} & \multicolumn{2}{|c|}{0,0014} & \multicolumn{2}{|c|}{0,0000} \\
\hline
\end{tabular}
Konvensional dan Syariah

Tabel 1. menunjukan hubungan faktor makro ekonomi dan kinerja keuangan perbankan, baik bank konvensional maupun bank syariah. Secara umum dapat dilihat bahwa nilai p-value BIRATE dan INF memiliki hubungan yang signifikan terhadap ROA, ROE dan NPL. Hal tersebut menunjukan bahwa kedua faktor makro ekonomi tersebut memiliki pengaruh yang sangat penting terhadap kinerja keuangan perbankan. Sementara itu, variabel GGDP hanya memiliki tingkat signifikansi terhadap ROE yang menunjukan bahwa semakin tinggi GGDP maka nilai ROE akan semakin rendah. Namun demikian, hubungan antara satu variabel dengan variabel lain dapat 
berbeda. Misalkan saja pada hubungan antara BIRATE dan ROE yang menunjukan arah yang negatif signifikan. Hal ini berarti bahwa jika suku bunga Bank Indonesia dinaikan, maka tingkat keuntungan perbankan akan semakin rendah. Hal tersebut diduga karena cost of borrowing yang diberikan bank kepada nasabah akan semakin tinggi dan menyebabkan nasabah perbankan memilih untuk menahan diri dalam melakukan pinjaman kepada perbankan.

Pada Tabel 2. Menunjukan hubungan faktor makro ekonomi dan kinerja keuangan di perbankan konvensional. Secara umum dapat dilihat bahwa model yang digunakan dalam penelitian ini adalah valid yang digambarkan oleh nilai $f$-statsyang signifikan. Namun demikian, hubungan antara satu variabel dengan variabel lain tidaklah sama. Misalkan saja pada hubungan antara INF dan ROE yang bersifat positif signifikan. Hal ini dapat diartikan bahwa meningkatnya tingkat inflasi akan diiringi dengan menginkatnya tingkat keuntungan perbankan konvensional terhadap equity yang dimiliki. Hal tersebut dimungkinkan bahwa tingginya tingkat inflasi diiringi dengan menigkatnya tingkat suku bunga yang menjadi acuan tingkat keuntungan perbankan. Pada akhirnya, dengan naiknya tingkat suku bunga acuan tersebut, maka tingkat keuntungan perbankan konvensional akan semakin tinggi karena menerima prosentasi pengembalian pinjaman yang lebih tinggi yang diperoleh dari nasabah perbankan konvensional.

Tabel 2. Hubungan Faktor Makro Ekonomi dan Kinerja Keuangan di Perbankan Konvensional

\begin{tabular}{|c|c|c|c|c|c|c|}
\hline \multirow{2}{*}{ Variabel } & \multicolumn{2}{|c|}{ ROE } & \multicolumn{2}{|c|}{ ROA } & \multicolumn{2}{|c|}{ NPL } \\
\hline & Koef & P-Value & Koef & P-Value & Koef & P-Value \\
\hline Konstanta & 32,407 & $0,00 * * *$ & 3,4659 & $0,00 * * *$ & 2,3994 & $0,00 * * *$ \\
\hline BIRATE & $-2,6037$ & $0,00 * * *$ & $-0,1906$ & $0,02 * *$ & 0,1283 & 0,268 \\
\hline INF & 0,9121 & $0,00 * * *$ & 0,0636 & $0,09 *$ & $-0,1576$ & $0,00 * * *$ \\
\hline GGDP & $-0,2145$ & $0,03 * * *$ & $-0,0087$ & 0,31 & 0,0184 & 0,173 \\
\hline Observasi & \multicolumn{2}{|c|}{216} & \multicolumn{2}{|c|}{216} & \multicolumn{2}{|c|}{216} \\
\hline Grup Panel & \multicolumn{2}{|c|}{9} & \multicolumn{2}{|c|}{9} & \multicolumn{2}{|c|}{9} \\
\hline R-Squared & \multicolumn{2}{|c|}{0,0353} & \multicolumn{2}{|c|}{0,0101} & \multicolumn{2}{|c|}{0,0495} \\
\hline F-Stats & \multicolumn{2}{|c|}{0,0000} & \multicolumn{2}{|c|}{0,0079} & \multicolumn{2}{|c|}{0,0000} \\
\hline
\end{tabular}

Padatabelterkahir, yakniTabel 3., menunjukanhubunganantarafaktormakroekon omidankinerjakeuangan di perbankansyariah. Secaraumum, tidakadaperbedaan yang signifikanantarapengaruhvariabelmakroekon omiterhadapkinerjakeuanganperbankansyaria h. Hal iniditunjukanolehnilaip-value yang cenderungmemberikanpolapengaruh yang samasepertiapa yang dialamiolehperbankankonvensional. Namundemikianadabeberapahalmenarik yang perludikajisepertihalnyapengaruh BIRATE terhadap ROE dan ROA yang memilikihubungannegatifsignifikan.

Hubunganantara BIRATE terhadap ROE dan ROA yang signifikanmenunjukanbahwaperbankansyaria hmasihterikatdengantingkatbungaacuan yang dirilisoleh Bank Indonesia dalamjangkawaktutertentu. Hal iniberarti, kinerja bank syariahmasihsangatdipengaruhiolehmakanis mesistemekonomi yang konvensionaldimanasukubungaacuan Bank 
Indonesiditempatkansebagai

salah satutolakukurdalammenetukantingkatkeuntun gan.

Hal tersebutsebenarnyamasihdapatdipahamikaren a Indonesia sendirimenggunakansistemdual bankingdimana

BI masihbanyakmenggunakanregulasi-regulasi yang

tidakberkesesuaiandenganprinsipsyariahmesk iharusdiakuaibahwa Bank Indonesia juga berupayauntukterusmemperbaikidiridenganm emberikanbanyakperaturan-

pertaurantertentusecarakhususkepadaperbank ansyariah.

Tentunyahalinibertujuanuntuklebihmemperba iki bank syariah agar sesuaidengantuntunansyariah.

Tabel 3. Hubungan Faktor Makro Ekonomi dan Kinerja Keuangan di PerbankanSyariah

\begin{tabular}{|c|c|c|c|c|c|c|}
\hline \multirow{2}{*}{ Variabel } & \multicolumn{2}{|c|}{ ROE } & \multicolumn{2}{|c|}{ ROA } & \multicolumn{2}{|c|}{ NPF } \\
\hline & Koef & P-Value & Koef & P-Value & Koef & P-Value \\
\hline Konstanta & 48,208 & $0,035 * *$ & 6,307 & $0,018 * *$ & $-5,7751$ & $0,00 * * *$ \\
\hline BIRATE & $-7,979$ & $0,01 * *$ & $-1,148$ & $0,069^{*}$ & 1,9038 & $0,024 * *$ \\
\hline INF & 2,723 & $0,00 * * *$ & 0,413 & 0,146 & $-0,6911$ & 0,144 \\
\hline GGDP & $-0,3133$ & $0,03 * *$ & $-0,047$ & 0,202 & 0,1200 & 0,25 \\
\hline Observasi & \multicolumn{2}{|c|}{216} & \multicolumn{2}{|c|}{216} & \multicolumn{2}{|c|}{216} \\
\hline $\begin{array}{l}\text { Grup } \\
\text { Panel }\end{array}$ & \multicolumn{2}{|c|}{9} & \multicolumn{2}{|c|}{9} & \multicolumn{2}{|c|}{9} \\
\hline $\begin{array}{l}\text { R- } \\
\text { Squared }\end{array}$ & \multicolumn{2}{|c|}{0,0686} & \multicolumn{2}{|c|}{0,0726} & \multicolumn{2}{|c|}{0,0495} \\
\hline F-Stats & \multicolumn{2}{|c|}{0,0024} & \multicolumn{2}{|c|}{0,0019} & \multicolumn{2}{|c|}{0,0000} \\
\hline
\end{tabular}

\section{PEMBAHASAN / DISCUSSION}

Berdasarkan hasil analisa data yang telah dijelaskan sebelumnya menunjukan bahwa faktor makro ekonomi seperti tingkat suku bunga Bank Indonesia, tingkat inflasi dan pertumbuhan GDP memiliki pengaruh yang signifikan terhadap kinerja perbankan baik diukur dengan tingkat keuntungan maupun resiko. Hal ini menunjukan bahwa industri perbankan di Indonesia harus memberikan perhatian yang besar terhadap dinamika faktor makro ekonomi yang sedang terjadi. Hal tersebut harus dilakukan oleh bank untuk dapat memberikan respon secara tepat terhadap kondisi ekonomi makro yang sedang dan akan terjadi kedepan.

Sementara itu, dalam konteks perbandingan kinerja antara perbankan konvensional dan syariah yang sama-sama dimiliki oleh perbankan tertentu menunjukan tidak ada perbedaan yang besar terhadap antara kinerja perbankan konvensional dan syariah terhadap faktor makro ekonomi. Kedua jenis perbankan tersebut memiliki tingkat kerentanan yang cenderung sama terhadap kondisi faktor makro ekonomi. Misalkan saja dalam hal pengaruh BIRATE dan GGDP yang mempunyai pengaruh negatif signifikan terhadap perbankan konvensional dan syariah. Hal tersebut menjadi salah satu justifikasi yang menyatakan bahwa baik perbankan syariah maupun konvensional memiki kerentanan yang hampir sama terhadap kondisi makro ekonomi. Fakta tersebut juga berarti bahwa perlakukan perbankan konvensional dan 
syariah dalam sistem operasional perbankan cenderung sama. Hal ini juga dapat dilihat dari model busnis perbankan syariah yang mirip dengan perbankan konvensional. Sehingga tidak mengherankan apabila tingkat kinerja baik dalam hal keuntungan dan resiko perbankan konvensional dan syariah dipengaruhi oleh faktor makro ekonomi yang sama.

\section{KESIMPULAN / CONCLUSSION}

\section{Kebijakan}

\section{Kesimpulan}

Dual banking system banyak digunakan oleh perbankan di Indonesia sebagai bentuk strategi bisnis. Sehingga, bank-bank syariah di Indonesia secara umum bukanlah perbankan yang dari awal berdiri sudah menjadi bank syariah, namun berasal dari unit usaha syariah bank konvensional. Dari hasil analisa data dan diskusi yang dilakukan menunjukan bahwa perbankan konvensional dan syariah memiliki tingkat kerentanan yang sama terhadap faktor makro ekonomi. Hal ini menunjukan bahwa tingkat sensitivitas kinerja keuangan perbankan konvensional dan syariah sangat dipengaruhi oleh faktor makro ekonomi seperti halnya tingkat suku bunga acuan Bank Indonesia, tingkat inflasi dan pertumbuhan GDP.

\section{Rekomendasi Kebijakan}

Dari hasil diketahui bahwa faktor makroekonomi memiliki dampak yang signifikan pada kinerja sistem perbankan ganda di Indonesia. Hal ini patut untuk menjadi perhatian bagi bank sentral dan pemerintah terkait penerapan kebijakan moneter maupun dalam sektor perbankan. Penerapan kebijakan antara perbankan konvensional maupun bank Islam harus memiliki acuan yang berbeda, karena prinsip pelaksaan kinerja kedua perbankan tersebut ialah berbeda.
Kondisi tingkat keuntungan perbankan Islam yang dipengaruhi oleh suku bunga bank Indonesia menunjukkan, bahwa perbankan Islam di Indonesia belum sepenuhnya dalam menjalan prinsip hukum Islam yang sesuai dan pertumbuhan yang sangan tinggi juga masih mempengaruhi kinerja dari sistem perbakna konvensional. Hal ini menunjukkan bahwa bank konvensional masih mengikuti arus trend ekonomi, seperti jika konsumsi meningka maka bank akan memberikan produk produk perbankan yang akan meningkat seseorang untuk berkonsumsi.

Hal ini perlu diperhatikan secara mendalam dan berikut saran yang dapat direkomendasikan, yakni pemerintah dan bank sentral perlu memiliki skema kebijakan yang bertujuan untuk mengontrol jalannya sistem kinerja perbankan ganda agar tetap dalam on the track, diperlukannya perluasan kajian mengenai makroprudensial dalam hal riset dan penelitian dengan model yang lebih inovatif, variabel yang lebih banyak dan sample yang lebih luas lagi, dan cakupan penelitian ini yang hanya terkait tiga instrumen yang mencerminkan sistem kinerja perbankan yaitu ROE, ROA, dan NPL/NPF maka diperlukan penelitian lebih lanjut mengenai instrumen sistem kinerja perbankan selain ROE, ROA, dan NPL/NPF.

\section{DAFTAR PUSTAKA / BIBLIOGRAPHY}

Ali, S. S. (2007). Financial Distress and Bank Failure: Lessons from Closure of Ihlas Finans in Turkey. Islamic Economic Studies, 14(1), 1-52.

Alper, D. dan Anbar, A. (2011). Bank Specific and Macroeconomic Determinants of Commercial Bank Profitability: Empirical Evidence from Turkey. Business and Economics Research Journal. Vol. 2, pp. 139-152

Alqahtani, F., Mayes, D. G., \& Brown, K. (2016). Economic turmoil and Islamic banking: Evidence from the Gulf Cooperation Council. Pacific Basin Finance Journal, 39, $44-56$. 
https://doi.org/10.1016/j.pacfin.2016.05.017

Ascarya dan Yumanita, Diana. (2009). Formulasi Indeks Stabilitas Keuangan dan Peran Perbankan Syariah dalam Sistem Keuangan Ganda di Indonesia. Tidak dipublikasikan. Jakarta: Bank Indonesia

Aviliani, Siregar, Hermanto., Maulana, Tubagus N.A., dan Hasanah, Heni. (2015). The Impact of Macroeconomics Conditions on The Bank's Performance in Indonesia. Buletin Ekonomi Moneter dan Perbankan. April Vol. 17 No. 4

Bourkhis, K., \& Nabi, M. S. (2013). Islamic and conventional banks' soundness during the 2007-2008 financial crisis. Review of Financial Economics, 22(2), 68-77. https://doi.org/10.1016/j.rfe.2013.01.001

IFSB (2016). Islamic Finance Stabibilty Report 2016. Islamic Finance Service Board.

Greene, William H. (2008). Econometric Analysis, 6th Edition. Prentice Hall: New Jearsey

Larionova, N., \& Varlamova, J. (2014). Correlation Analysis of Macroeconomic and Banking System Indicators. Procedia Economics and Finance, 14(14), 359-366. https://doi.org/10.1016/S22125671(14)00724-2

Masood, O., \& Ashraf, M. (2012). Bank-specific and macroeconomic profitability determinants of Islamic banks: The case of different countries. Qualitative Research in Financial Markets, 4(2/3), 255-268. https://doi.org/10.1108/1755417121125256 5

Meslier, C., Risfandy, T., \& Tarazi, A. (2016).
Dual market competition and deposit rate setting in Islamic and conventional banks. SSRN Working Paper, 63(July), 318-333. https://doi.org/10.13140/RG.2.1.3596.1841

Mishkin, F.S. (2001). The Economics of Money, Banking, and Financial Markets. New York: Columbia University.

OJK. (2016). Booklet Perbankan di Indonesia 2016. Otoritas Jasa Keuangan

OJK. (2016). Statistik Perbankan Syariah Desember 2016. Otoritas Jasa Keuangan

Olson, D., \& Zoubi, T. (2016). Convergence in bank performance for commercial and Islamic banks during and after the Global Financial Crisis. The Quarterly Review of Economics and Finance. https://doi.org/10.1016/j.qref.2016.06.013

Rashid, A., \& Jabeen, S. (2016). Analyzing performance determinants: Conventional versus Islamic Banks in Pakistan. Borsa Istanbul Review, 16(2), 92-107. https://doi.org/10.1016/j.bir.2016.03.002

Silalahi, Tumpak, Adler H., Yuli Teguh. (2015). The Market Structure of The Bank, Its Performance, and The Macroprudential Policy. Buletin Ekonomi Moneter dan Perbankan Vol 18: 1. Jakarta: Bank Indonesia

Zarrouk, H., Ben Jedidia, K., \& Moualhi, M. (2016). Is Islamic bank profitability driven by same forces as conventional banks? International Journal of Islamic and Middle Eastern Finance and Management, 9(1), 46-66. https://doi.org/10.1108/IMEFM-122014-0120 